\title{
ANALISIS DAN EVALUASI TERHADAP PANDANGAN THOMAS AQUINAS TENTANG GAMBAR ALLAH
}

\author{
Adi Putra \\ Sekolah Tinggi Teologi Pelita Dunia \\ addiepoetra7@gmail.com
}

\begin{abstract}
This study discusses the analysis and evaluation of Thomas Aquinas's view of the "image of God". Through qualitative research with a literature review approach, the following conclusions are obtained Aquinas's view of God's image is very unbiblical. Because it is more inclined to the philosophy of Plato and Aristotle. This is a characteristic of scholastic group theology. Because scholastic theologians tend to place ratios more dominant in theology than the Bible. Furthermore, the image of God carried by humans is not only in the ratio, but in the totality of human existence in the earth as God's representative. The image of God in humans experiences severe damage after the fall of man in sin. The ratio is no better than the body. In other words, all parts of human beings, whether spirit, ratio, morals, body, when created in a noble or very good state. This rejects Aquinas's view that there are inferior forces. Finally, through this research we want to stress that the image of the true God is in Christ. This has the effect that it is only through Christ that the image of God that has been badly damaged can be repaired.
\end{abstract}

Keywords: Thomas Aquinas, God's Image, Analysis, Evaluation

Abstrak: $\quad$ Penelitian ini membahas tentang analisis dan evaluasi terhadap pandangan Thomas Aquinas tentang "gambar Allah". Melalui penelitian kualitatif dengan pendekatan kajian pustaka maka diperoleh kesimpulan sebagai berikut Pandangan Aquinas tentang Gambar Allah sangat tidak alkitabiah. Oleh karena lebih cenderung kepada filsafat Plato dan Aristoteles. Ini merupakan ciri khas dari teologi kelompok skolastik. Oleh karena teolog skolastik cenderung menempatkan rasio lebih dominan dalam berteologi dibanding Alkitab. Selanjutnya, gambar Allah yang disandang oleh manusia tidak hanya terdapat pada rasio saja, melainkan pada totalitas eksistensi manusia di bumo sebagai wakil Allah. Gambar Allah pada manusia mengalami kerusakan yang parah pasca kejatuhan manusia dalam dosa. Rasio tidak lebih baik dari pada tubuh. Dengan kata lain, seluruh bagian dari manusia, baik roh, rasio, moral, tubuh, ketika diciptakan dalam keadaan yang mulia atau sungguh amat baik. Hal ini menolak pandangan Aquinas yang menyatakan bahwa ada kekuatan-kekuatan yang lebih rendah. Terakhir, melalui penelitian ini hendak ditegaskan bahwa gambar Allah yang sejati ada dalam Kristus. Hal ini memberi dampak bahwa hanya melalui Kristus-lah gambar Allah yang telah rusak parah dapat diperbaiki.

Kata kunci: Thomas Aquinas, Gambar Allah, Analisis, Evaluasi 


\section{PENDAHULUAN}

Thomas Aquinas lahir di Roccasecca, dekat Aquino, di Italia, pada tahun 1225. Ayah Aquinas adalah Pangeran Landruf dari Aquino. Aquinas pada umur lima tahun telah diserahkan ke Biara Benedictus di Monte Cassino untuk menjadi biarawan. Sepuluh tahun setelah di Biara Benedictus, ia pindah ke Naples untuk belajar bahasa. Aquinas di Naples mulai tertarik kepada pekerjaan kerasulan Gereja dan masuk ke ordo Dominikan. ${ }^{1}$ Orang tua Aquinas pada awalnya tidak menyetujui keinginan untuk menjadi seorang Dominikan, sehingga Aquinas kembali dan tinggal di Roccasecca lebih dari setahun. Sekitar tahun 1245 Aquinas dapat meyakinkan orangtuanya dan diizinkannya masuk ordo Dominikan. ${ }^{2}$

Tahun 1245-1248 Aquinas belajar di Universitas Paris. Aquinas berkenalan dengan Albertus Magnus yang kemudian memperkenalkan dan mengajarkan filsafat Aristoteles. Aquinas tinggal dengan Magnus selama tiga tahun, kemudian pada tahun 1248 Aquinas mengikuti Magnus ke Cologne. Aquinas selama beberapa tahun tinggal dengan para filsuf dari kelompok skolastik yang memberikan pengaruh sangat penting dalam perkembangan studi yang menyeluruh dan permanen mengikuti filsafat Aristoteles. ${ }^{3}$

Aquinas pergi ke Paris pada tahun 1252 dan mulai mengajar beberapa tahun dan di Paris serta mulai menulis beberapa ajaran. Aquinas menjadi sangat terkenal karena kecakapan mengajar, sehingga diberikan tugas untuk mengajar filsafat dan teologi dibeberapa kota Italia, yaitu Anagni, Orvieto, Roma dan Viterbo selama sepuluh tahun. ${ }^{4}$ Aquinas dipanggil kembali ke Paris pada tahun

\footnotetext{
1Ramadhon, "Kebahagiaan Dalam Pandangan Thomas Aquinas Dan Hamka," http://journal.uinjkt.ac.id/index.php/una/article/download/15159/pdf, t.t, 38-39.

2 Christopher M. Brown, https://www.lep.Utm.Edu/Aquinas/, n.d

3 "https://id.wikipedia.org/wiki/Thomas_Aquinas," t.t.

${ }^{4}$ Christopher M. Brown, https://www.iep.utm.edu/aquinas/, t.t.
} 
1269 dan ditugaskan untuk untuk membuka sebuah sekolah milik kelompok Dominikan di Naples. Paus menunjuk Aquinas menghadiri Konsili di Lyons pada awal tahun 1274. Aquinas melalukan perjalanan ke Lyons, karena sakit perjalanan berhenti pada sebuah Kastil. Aquinas ingin mengakhiri hidup dalam sebuah biara. Aquinas pada akhirnya dibawa ke biara Fossanuova dan meninggal pada 7 Maret 1274. Tahun 1323 Paus Yohanes XXII mengangkatnya sebagai Santo (orang kudus). ${ }^{5}$

Aquinas memiliki ajaran tentang gambar Allah berada di dalam kecerdasan atau rasio manusia. Ajaran Aquinas berdampak kepada pandangan bahwa hanya makhluk yang cerdaslah yang dapat dikatakan sebagai gambar Allah. Aquinas berpandangan bahwa malaikat memiliki gambar yang lebih sempurna daripada manusia, karena konsep malaikat memiliki kecerdasan yang lebih dari manusia. ${ }^{6}$ Jadi inti ajaran Aquinas tentang gambar Allah hanya ditemukan dalam pikiran atau rasio. Anthony A. Hoekma menuliskan bahwa Aquinas mengajarkan gambar Allah dapat bereksistensi di dalam diri manusia pada tiga tingkat, yakni:

Tingkat pertama adalah potensi alamiah manusia untuk memahami dan mengasihi Allah. menurut Aquinas, potensi ini ada di dalam natur pikiran itu sendiri dan terdapat pada semua manusia; Tingkat kedua adalah di mana seseorang secara aktual atau secara kebiasaan mengenal dan mengasihi Allah - tetapi secara tidak sempurna. Manusia memiliki gambar tersebut melalui pembentukan oleh anugerah Allah; dan Tingkat ketiga adalah tahap di mana seseorang secara aktual mengenal dan mengasihi Allah secara sempurna; dan inilah gambar yang serupa dengan kemuliaan. ${ }^{7}$

Berdasarkan pemahaman di atas, maka dapat dikatakan bahwa gambar Allah dalam pengertian tertentu dapat dijumpai dalam diri semua manusia, akan

\section{${ }^{5}$ Brown}

${ }^{6}$ Anthony A. Hoekema, Manusia: Ciptaan Menurut Gambar Allah (Surabaya: Momentum, 2003), 46-47.

7 Hoekema, 47. 
tetapi pada tingkat yang sedikit lebih tinggi hanya terdapat dalam diri orang percaya dan pada tingkat tertinggi hanya dapat dijumpai dalam diri orang-orang yang telah dipermuliakan. Jadi, semua manusia masih memiliki gambar Allah meskipun dalam tingkatan kualitas yang berbeda.

Aquinas mengajarkan prinsip penting lain tentang tentang keadaan gambar Allah sebelum kejatuhan manusia. Hoekema menuliskan dua argumentasi tentang ajaran Aquinas tersebut:

Pertama, pada mulanya saat manusia diciptakan, di dalam dirinya terjadi pergumulan antara rasio dengan 'hasrat yang lebih rendah' atau 'kekuatankekuatan yang lebih rendah', seperti emosi, selera makan dan dorongan seksual. Kedua, pada mulanya manusia diciptakan, dia memerlukan pemberian berupa anugerah supranatural untuk memampukannya memakai akal budi guna mengendalikan 'kekuatan-kekuatan yang lebih rendah' yang dia miliki. ${ }^{8}$

Berdasarkan penjelasan konsep Aquinas terhadap gambar Allah prakejatuhan, maka terlihat jelas bahwa Aquinas mendikotomikan rasio dengan emosi. Aquinas mengajarkan rasio adalah hal yang paling unggul bila dibandingkan dengan emosi. Aquinas juga mengajarkan bahwa manusia memerlukan anugerah yang sifatnya supranatural untuk mengendalikan emosi, yang dianggap sebagai kekuatan-kekuatan yang rendah.

Aquinas mengajarkan pada waktu manusia diciptakan, akal budinya tunduk kepada Allah, kekuatan lebih rendah yang dimiliki tunduk kepada rasionya, dan tubuhnya tunduk pada jiwanya, tetapi penundukan kekuatankekuatan yang lebih rendah kepada rasio, serta penundukan tubuh kepada jiwa bukanlah hal yang alamiah, karena apabila demikian maka pasti akan terus bertahan setelah kejatuhan manusia dalam dosa. ${ }^{9}$ Aquinas menambahkan bahwa 
karena dosa, manusia pertama tidak lagi memiliki bantuan ilahi untuk mempertahankan integritas natur manusia di dalam dirinya, karena manusia kehilangan anugerah supranatural dan sekarang tidak lagi memiliki kemampuan untuk mengendalikan kekuatan-kekuatan yang lebih rendah yang dimiliki dengan akal budinya. ${ }^{10}$ Dengan demikian Aquinas memiliki konsep ketika manusia berdosa gambar Allah dalam diri manusia tidak mengalami kerusakan total, atau dengan kata lain 'tetap baik-baik saja', hanya saja, manusia kehilangan anugerah supranatural yang berfungsi untuk membantu rasio/akal budi mengendalikan emosi.

Penulis memperhatikan dengan seksama pandangan Aquinas tentang gambar Allah cenderung lebih banyak dipengaruhi oleh filsafat. Penulis meneliti perbedaan prinsip pengajaran tentang gambar Allah setelah jatuh ke dalam dosa, antara ajaran Aquinas dan prinsip Alkitab. Perbedaan ajaran ini merupakan sebuah problematika teologis yang perlu dijelaskan dalam penelitian ini. Ajaran Aquinas tentang kondisi gambar Allah yang menempatkan gambar Allah itu hanya terdapat pada aspek rasional manusia sudah berbeda dengan apa yang Alkitab ajarkan. Oleh karena itu melalui penelitian ini penulis memberikan analisis dan evaluasi secara teologis dan eksegetis terhadap pandangan Aquinas tentang gambar Allah.

\section{METODE}

Pada penelitian ini menggunakan pendekatan kualitatif dengan pendekatan kajian pustaka. ${ }^{11}$ Penulis meneliti literatur filsafat dan literatur yang membahas tentang biografi Aquinas untuk memahami latar belakang kehidupannya.

10 Hoekema, 50.

11 Imam Gunawan, "Metode penelitian kualitatif" (Universitas Negeri Malang, 2013), http://fip.um.ac.id/wp-content/uploads/2015/12/3_Metpen-Kualitatif.pdf. 
Penulisan menerapkan metode evaluasi dalam menyelesaikan problematika. ${ }^{12}$ Evaluasi dilakukan dengan melakukan pengumpulan data didasarkan pada literatur-literatur teologi yang dianalisis dan diteliti dengan baik untuk memperoleh sebuah hasil penelitian kualitatif. Literatur-literatur yang diteliti dalam penelitian ini berkisar seputar literatur-literatur teologi dengan mengkombinasikannya dengan beberapa lexicon hingga commentary guna menemukan informasi yang valid tentang "gambar Allah" dalam versi ajaran dan teologi yang Alkitabiah. Pada bagian akhir penulis akan menuliskan kesimpulan yang berisi kebaharuan dari hasil evaluasi terhadap ajaran Thomas Aquinas tentang gambar Allah.

\section{HASIL}

Melalui proses penelitian kualitatif (analisis dan evaluasi) dengan pendekatan kajian pustaka terhadap pandangan Thomas Aquinas tentang "gambar Allah" maka akan dihasilkan deskripsi tentang pandangan Thomas Aquinas tentang gambar Allah dan konsep gambar Allah yang sesuai dengan konsep Alkitab. Metode evaluasi penelitian ini dengan memberikan pembuktikan literatur yang menunjukkan bahwa gambar Allah tidak hanya pada rasio manusia, tetapi mencakup seluruh eksistensi manusia, selanjutnya evaluasi ini menghasilkan konsep status gambar Allah yang telah rusak total dan bahwa Yesus Kristus adalah gambar Allah yang sejati. Dengan demikian penelitian ini menghasilkan sebuah antitesis antara pandangan tentang gambar Allah menurut Thomas

12 Michael Quinn Patton, Budi Puspo Priyadi, dan Kamdani, Metode evaluasi kualitatif (Pustaka Pelajar, 2006), 1. 
Aquinas dan konsep. Antitesis penelitian ini merupakan kebaharuan yang penulis dapatkan dari penelitian yang telah dilakukan.

\section{PEMBAHASAN}

Dalam pembahasan ini penulis akan menjelaskan tentang latar belakang teologi Thomas Aquinas, ajaran Alkitab tentang gambar Allah yang memfokuskan pada pembahasan gambar Allah adalah totalitas eksistensi manusia, kejatuhan berdampak serius kepada gambar Allah, gambar Allah dipulihkan melalui Yesus Kristus dan pandangan masa kini tentang gambar Allah. Pada bagian akhir penulis melakukan analisis terhadap pengajaran Thomas Aquinas tentang gambar Allah.

\section{Latar Belakang Teologi Thomas Aquinas}

Biografi Aquinas yang dituliskan pada pendahuluan telah menjelaskan bahwa Aquinas adalah seorang Dominikan yang merupakan anak didik dari Magnus. Pada waktu dia studi teologi di Universitas Paris, Magnus memperkenalkannya dengan filsafat Aristoteles. Sehingga dia mejadi terkenal dan dikagumi banyak orang (khususnya dari RK), oleh karena dia dapat mensintesiskan antara filsafat Aristoteles dengan ajaran Alkitab. Salah satu contoh ajaran Aquinas yang menunjukkan bahwa dia begitu kuat dipengaruhi oleh filsafat Aristoteles (juga filsafat Plato) ketika mengemukakan tentang The Five Ways untuk mengetahui keberadaan Allah. Colin Brown menuliskan:

Aquinas percaya bahwa seseorang dapat berdalih mundur dari hal-hal yang kita amati di dunia ini sampai suatu penggerak utama, suatu penyebab/kausa pertama atau seorang perancang agung di baliknya...Setiap kejadian harus ada penyebabnya. Tidak ada satu pun yang menyebabkan dirinya sendiri". ${ }^{13}$

${ }^{13}$ Collin Brown, Filsafat dan Iman Kristen Jilid 1 (Surabaya: Momentum, 2011), 31. 
Ajaran di atas diambil dari pandangan Aristoteles tentang suatu penggerak yang tidak digerakkan. Aquinas dalam tulisannya yang terkenal, Summa Theologiae, pada bagian kedua yang berbicara tentang Etika, menjadikan kebajikan etika dari Aristoteles sebagai tolok ukur, meskipun, tidak persis sama dengan Aristoteles, Aquinas berargumentasi untuk menghubungkan antara kesalehan (virtuous) manusia dan Allah melalui penjelasan kesalehan tindakan yang mengarahkan kepada kebahagiaan dari Beatific Vision. ${ }^{14}$ Dengan demikian, menjadi sangat jelas bahwa teologi Aquinas begitu kuat dipengaruhi oleh skolastik dan filsafat Aristoteles dan Plato. Ajaran Aquinas tidak murni didasarkan kepada Alkitab, akan tetapi justru lebih condong kepada filsafat. Brown mengatakan, "Pemikirannya merupakan campuran antara ajaran Alkitab, tradisi-tradisi gereja, dan filsafat, khususnya pandangan Aristoteles...". ${ }^{15}$ Aquinas berasal dari kelompok skolastik. ${ }^{16}$ Di mana menurut Enns, "Ada tiga bentuk skolastikisme, yaitu: Realisme, ${ }^{17}$ yang mengikuti Plato; Realis moderat ${ }^{18}$ yang mengikuti Aristoteles; dan Nominalis". ${ }^{19}$ Jadi Aquinas lebih cocok disebut sebagai seorang filsuf dan seorang teolog.

\section{Ajaran Alkitab Tentang Gambar Allah}

Penulis pada bagian ini akan memberikan konsep ajaran Alkitab tentang gambar Allah, bagian ini merupakan landasan teori yang akan dijadikan sebagai alat evaluasi ajaran Thomas Aquinas tentang gambar Allah. Penulis pada bagian ini mengajukan pertanyaan penting, yaitu apa yang diajarkan Alkitab tentang

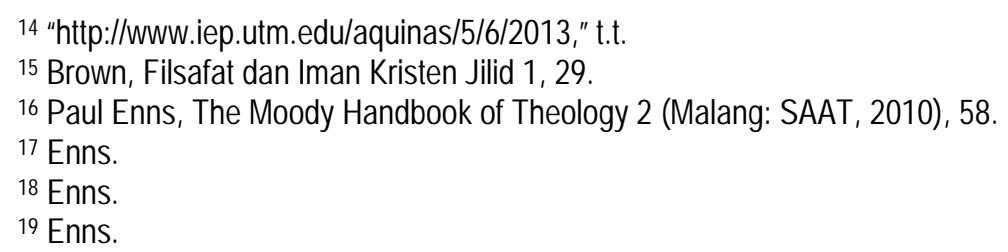


manusia diciptakan menurut gambar Allah? Sehingga menjadikan manusia sebagai satu-satunya makhluk ciptaan Tuhan yang menyandang gambar Allah. Penulis memberikan beberapa poin pandangan Alkitab, baik Perjanjian Lama maupun Perjanjian Baru tentang gambar Allah.

\section{Gambar Allah Adalah Totalitas Eksistensi Manusia}

Kejadian pasal 1 menuliskan tentang kisah penciptaan manusia, khususnya ayat 26-28 tersurat satu frasa yang berbunyi, "Baiklah Kita menjadikan manusia menurut gambar dan rupa Kita.” Dalam terjemahan Lembaga Alkitab Indonesia (selanjutnya disingkat LAI) sangat jelas tersurat bahwa antara kata 'gambar' dengan 'rupa' terdapat kata penghubung 'dan' yang sama dijumpai apabila melihat terjemahan Septuaginta (LXX) dan Vulgata. Akan tetapi, apabila memperhatikan teks aslinya dengan seksama, maka sangat jelas bahwa kata penghubung 'dan' sama sekali tidak ada, dalam teks bahasa Ibrani dituliskan -

ל yang diterjemahkan "Lalu Allah berfirman:

"Marilah Kita menjadikan manusia menurut gambar rupa Kita."20 Sehingga menjadi jelas bahwa tidak ada perbedaan yang esensi di antara kata 'gambar' dan 'rupa.' Brown, Driver dan Briggs, menjelaskan kata (tselem):

(1) image of tumours and mice (of gold) 1 S 6:5, 6:5, 6:11; esp. of heathen gods Am 5:26 (text dub.; del. We as gloss, cf. GASm Dr), 2 K 11:18 = 2 Ch 23:17 (both c. vb. ), Ez 7:20, so 16:17 (i.e. in male form, acc. to fig. of harlotry for idolatry); $\quad \mathrm{Nu} 33: 52$ their molten images; of painted pictures of men Ez 23:14; (2) image, likeness, of resemblance, ( ) , of God's making man in his own image, Gn 1:26 ( ), $\mathrm{v}: 27, \mathrm{v}: 27,9: 6, \quad 5: 3(\| \quad$; all P). (3) fig. = mere, empty, image, semblance, Psalm 39:7 as ( essentiae) a (mere) semblance man walks about; $\quad$ 73:20 thou wilt despise their semblance". ${ }^{21}$

20 Richard L. Pratt, Designed For Dignity (Surabaya: Momentum, 2002), 8.

21 C. Briggs F. Brown, S. Driver, The Brown-Driver Briggs Hebrew and English Lexicon (Hendrickson Publishers, 1907). 
Berdasarkan definisi yang diberikan di atas maka dapat dipahami bahwa kata ' ' dapat diartikan sebagai 'patung, gambar yang menyerupai.' Kemudian hal ini dipertegas oleh kata (demut), untuk memahami kata tersebut maka Brown, Driver dan Briggs, menjelaskan kata $\quad$ (demut), sebagai berikut:

(1) likeness, similitude, of external appearance, chiefly in Ezek.: Ez 1:5 (likeness, i.e. something that appeared like) so v:26, 8:2 ( )

(cf. Co), 10:1 ; cf. also Dn 10:16 i.e. one like the sons of man; similitude, resemblance Ezra 1:5, 1:10, 1:16, 1:22, 1:26, 10:10, 10:21, 10:22; $\quad 1: 26 ; \quad$ v:28; also 2 Raj. 16:10 (pattern of altar), 2 Ch 4:3 (images of oxen); of son in likeness of father Gn 5:3 (P); so also of man in likeness of God Gen. 1:26 (\| ) 5:1 (both P); cf. Is 40:18 what will ye compare to him ( ) ? \| q.v.; (2) adverbially, in likeness of, like as Is 13:4 cf. Ez 23:15 \& Psalm 58:5.Ez 1:13 rd. , v. and J P Peters:JBL 1892 40. 42. On Ez 1:16, 10:10 (apparently masc.) cf. Thes \& Sm who trans. the likeness of one had they all four; Co rds. " "22

Dengan demikian berdasarkan penjelasan kata (tselem) dan

(demut) dapat dikatakan bahwa gambar Allah yang disandang oleh manusia mencakup totalitas keberadaan manusia, sehingga berdasarkan penjelasan ini manusia memiliki otoritas menjadi wakil Allah di bumi. Hal yang serupa dikemukakan oleh Hamilton, "Genesis 1:26 is simply saying that to be human is to bear the image of God. This understanding emphasizes man is as a unity. No part of man, no function of man is subordinated to some other, higher part or activity." 23 Demikian juga dengan Hoekema, "Kedua kata itu memberi tahu kita bahwa manusia merepresentasikan Allah dan menyerupai Dia di dalam hal-hal tertentu". ${ }^{24}$ Yang kemudian dipertegas oleh Pratt, “...Menjadi representatif

22 F. Brown, S. Driver.

23 Victor P. Hamilton, The New International Commentary on The Old Testament: The Book of Genesis Chapter 1-17 (Michigan, USA: Grand Rapids, 1990), 137.

${ }^{24}$ Hoekema, Manusia: Ciptaan Menurut Gambar Allah, 18. 
pemerintahan-Nya di atas bumi". ${ }^{25}$ Berkhof menyimpulkan gambar Allah yang disandang manusia memiliki beberapa cakupan:

"(1)Dalam jiwa atau roh manusia yaitu dalam kualitas kesederhanaan, spiritualitas, tidak dapat dilihat dan kekal; (2) dalam kekuatan fisik manusia sebagai keberadaan rasional dan moral, yaitu intelektual dan kehendak dengan segala fungsinya; (3) dalam integritas intelektual dan moral dari natur manusia yang terungkap dalam pengetahuan yang benar, kebenaran dan kesucian, [Ef. 4:24; Kol. 3:10]; (4) dalam tubuh, bukan sebagai substansi material tetapi sebagai alat yang sesuai bagi jiwa, yang juga kekal - dan sebagai alat yang olehnya manusia dapat menguasai makhluk ciptaan yang lain; (5) dalam kuasa manusia atas bumi". ${ }^{26}$

Dengan demikian, gambar atau rupa Allah yang disandang oleh manusia mencakup totalitas eksistensi manusia di bumi, di mana manusia menjadi wakil Allah untuk menegakkan hukum-hukum Allah dan memancarkan kemuliaan Allah di bumi. Pemahaman ini lebih Alkitabiah dibanding dengan pemahaman Aquinas yang hanya melihat gambar Allah dalam rasio manusia saja.

\section{Kejatuhan Berdampak Serius Kepada Gambar Allah}

Penulis menjelaskan pada bagian ini mengenai dampak yang ditimbulkan oleh kejatuhan manusia dalam dosa terhadap gambar Allah yang disandang manusia. Berdasarkan pandangan Aquinas yang telah dikemukakan sebelumnya, bahwa manusia hanya kehilangan anugerah supranatural, sedangkan gambar Allah yang terdapat dalam rasio manusia baik-baik saja. Maka Aquinas menyatakan kejatuhan dalam dosa tidak memberikan efek yang serius bagi gambar Allah yang disandang oleh manusia.

Penulis menjelaskan yang Alkitab ajarkan secara khusus setelah Kejadian 3, dijelaskan betapa jahat manusia yang telah diciptakan Allah dalam keserupaan dengan-Nya. Kejahatan manusia memberikan sebuah indikasi teologis, apakah

25 Pratt, Designed For Dignity, 20.

${ }^{26}$ Louis Berkhof, Teologi Sistematika 2: Doktrin Manusia (Surabaya: Momentum, 1995), 56. 
gambar Allah itu telah hilang?. Dalam Kejadian 5: 1-3 dan 9: 6 Allah memberikan konfirmasi bahwa gambar Allah itu masih ada. Calvin menuliskan, "Manusia yang telah jatuh tetap memiliki gambar Allah. Menurutnya, gambar Allah tidak secara total musnah oleh kejatuhan melainkan wujudnya rusak parah."27 Kejadian 9: 6 menunjukkan apa yang dikemukakan oleh Calvin adalah tepat, oleh karena Tuhan tahu bahwa kejahatan manusia semakin besar di bumi dan itulah sebabnya dalam ayat 6 , Tuhan memberikan ganjaran bagi mereka yang berbuat jahat terhadap manusia yang lain. Seperti yang dikemukakan oleh Hamilton, "In other words, this verse does not at all delegate authority to man to institute capital punishment. The implication of 'for that man his blood shall be shed' is that God will administer the punishment." 28 Dengan demikian ayat tersebut tidak menjelaskan bahwa Tuhan memberikan hukuman kepada manusia yang menumpahkan darah sesamanya.

Manusia dianggap bersalah apabila menumpahkan darah manusia yang lain, karena semua manusia masih menyandang gambar atau rupa Allah meskipun telah berdosa. Sproul menuliskan, "Pada waktu kejatuhan, sesuatu yang tragis telah terjadi. Gambar Allah telah sangat tercemar. Kemampuan kita untuk mencerminkan kekudusan Allah telah sedemikian tercemar, sehingga sekarang cermin itu sangat kabur." ${ }^{29}$ Maka kejatuhan manusia ke dalam dosa tidak menghilangkan gambar Allah, tetapi mencemarkan gambar Allah sehingga manusia tidak berada dalam kekudusan. Yakobus 3: 9 menyatakan: " Dengan lidah kita memuji Tuhan, Bapa kita; dan dengan lidah kita mengutuk manusia

\footnotetext{
27 Hoekema, Manusia: Ciptaan Menurut Gambar Allah, 56.

28 Hamilton, The New International Commentary on The Old Testament: The Book of Genesis Chapter 1-17, 315.

${ }^{29}$ R.C. Sproul, Kebenaran-kebenaran Dasar Iman Kristen (Malang: SAAT, 2008), 172.
} 
yang diciptakan menurut rupa Allah." Ayat tersebut memberikan indikasi kuat bahwa manusia yang telah berdosa tetap menyandang gambar atau rupa Allah. Kata 'rupa' dalam teks aslinya menggunakan kata ó oíwoıv (omoiosin) berasal dari kata ó oíwor (omoiosis). Friberg memberikan penjelasan, "as an action making similar or like; in the New Testament, as a state of similarity likeness, resemblance. "30 Maka kata tersebut memiliki makna sebagai tindakan membuat serupa, dalam Perjanjian Baru sebagai keadaan kesamaan rupa. Kemudian kata

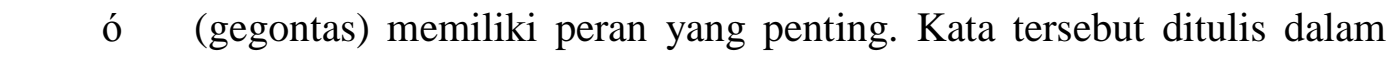
bentuk perfek, sehingga hendak menegaskan bahwa manusia sejak lampau telah menjadi (dijadikan) gambar Allah dan saat ini pun masih tetap menyandang gambar Allah. Hal ini kemudian dipertegas oleh Heokema,

Dalam ayat 9 Yakobus menunjukkan ketidakkonsistenan orang-orang berdosa karena memakai lidah yang sama untuk memuji Allah dan mengutuk manusia. Mengapa ini merupakan ketidakkonsistenan? Karena umat manusia yang kita kutuk - perhatikan bahwa Yakobus memakai kata ganti orang pertama - adalah ciptaan yang dijadikan menurut rupa Allah. Dengan demikian, mengutuk manusia sama dengan mengutuk Allah, yang menurut rupa-Nya manusia dijadikan. ${ }^{31}$

Berdasarkan bukti-bukti dari Alkitab mengindikasikan bahwa pasca kejatuhan, manusia tetap menyandang gambar Allah, akan tetapi gambar Allah tersebut sudah sangat rusak (kerusakan total), sehingga kecenderungan manusia tidak lagi mencerminkan kemuliaan Allah. Manusia melakukan yang sebaliknya yaitu hal-hal yang menyakiti Allah. Dengan demikian kejatuhan manusia ke dalam dosa memberikan dampak yang serius terhadap eksistensi gambar Allah pada setiap manusia. Penjelasan di atas memberikan pemikiran bahwa betapa perlunya pemulihan gambar yang telah rusak oleh dosa, namun disisi lain

30 Timothy Friberg, Analytical Greek Lexicon (Trafford Publishing, 2005).

${ }^{31}$ Hoekema, Manusia: Ciptaan Menurut Gambar Allah, 26. 
menjelaskan bahawa manusia tidak mampu dengan usahanya sendiri untuk memulihkan gambar Allah pada dirinya.

\section{Gambar Allah Dipulihkan Melalui Yesus Kristus}

Perjanjian Baru menegaskan bahwa gambar Allah yang telah rusak dipulihkan hanya di dalam dan melalui Yesus Kristus. Konsep ini secara khusus dapat ditemukan dalam Perjanjian Baru di mana Yesus Kristus dinyatakan sebagai gambar Allah yang sempurna. Penjelasan tentang Yesus Kristus sebagai gambar Allah yang sejati dapat ditemukan dalam beberapa ayat Alkitab, seperti di dalam 2Korintus 4: 4, Kolose 1: 15 dan Ibrani 1: 3. Dalam 2 Korintus 4: 4 dan Kolose 1: 15, kata 'gambar' menggunakan kata eỉkòv (eikon). ${ }^{32}$ Kata ini setara dengan kata Ibrani, 'tselem'. Mengenai kata tersebut Hoekema menjelaskan, ’Kemuliaan Allah dinyatakan dalam wajah Kristus; ketika kita melihat Kristus, kita melihat kemuliaan Allah."33 Sedangkan dalam Ibrani 1: 3, kata 'gambar' menggunakan kata $\chi \alpha \rho \alpha \kappa \tau \eta ̀ \rho ~(k h a r a k t h e r) .{ }^{34}$ Vine menjelaskan, "Kata ini bermakna cap atau cetakan, seperti pada sebuah koin atau meterai, di mana meterai yang dicap menyandang gambar yang dihasilkan oleh cap itu. Sebaliknya, semua aspek dari gambar yang dihasilkan tersebut, persis sama dengan aspek-aspek yang ada pada sarana yang menghasilkannya." ${ }^{35}$ Dengan demikian Berdasarkan beberapa informasi di atas, maka dapat dikatakan bahwa Yesus adalah gambar Allah yang sejati. Sehingga cara terbaik untuk belajar tentang gambar Allah adalah dengan

32 Walter Bauer's, A Greek-English Lexicon of The New Testament And Other Early Christian Literature (BDAG) Third Edition., ed. oleh Frederick William Danker. (Chicago: The University of Chicago Press, 2000), 281-282.

33 Hoekema, Manusia: Ciptaan Menurut Gambar Allah, 27.

${ }^{34}$ Bauer's, A Greek-English Lexicon of The New Testament And Other Early Christian Literature (BDAG) Third Edition, 1077-1078.

35 Hoekema, Manusia: Ciptaan Menurut Gambar Allah, 28. 
memandang kepada Kristus. Gambar Allah yang sejati inilah yang kemudian dapat memulihkan gambar Allah yang telah rusak dalam manusia.

Perjanjian Baru menyatakan perlunya pemulihan gambar Allah yang telah rusak karena dosa, dan itu hanya dapat dilakukan di dalam dan melalui Yesus Kristus (Lih. Rom. 8:29; 2Kor. 3: 18). Hoekema memberikan penjelasan mengenai kedua ayat tersebut demikian:

Baik Roma 8: 29 maupun 2Korintus 3: 18 mengajarkan bahwa tujuan dari penebusan umat Allah adalah agar kita sepenuhnya sesuai dengan gambar Kristus. Tetapi, jika dalam Roma kesesuaian dengan gambar Kristus dilihat sebagai tujuan dari tindakan Allah mempredestinasikan kita, maka 2 Korintus menekankan ciri progresif dari perubahan ini di sepanjang kehidupan sekarang dan fakta bahwa perubahan itu merupakan karya Roh Kudus. ${ }^{36}$

Meskipun kedua perikop di atas memiliki latar belakang berbeda dari tujuan pemulihan gambar Allah yang telah rusak dalam diri manusia. Namun satu hal yang perlu digarisbawahi adalah manusia yang merupakan gambar Allah yang telah rusak karena dosa perlu untuk dipulihkan, disesuaikan ke dalam gambar Kristus yang adalah gambar Allah yang sejati. Dengan demikian Yesus Kristus adalah model utama dari gambar Allah yang sejati yang sanggup memulihkan kerusakan gambar Allah yang disandang oleh manusia.

\section{Pandangan Masa Kini Tentang Gambar Allah}

Penulis memberikan kesimpulan berdasarkan di atas tentang ajaran Alkitab mengenai gambar Allah pada manusia, dapat disimpulkan beberapa hal: Pertama, gambar Allah dalam diri manusia bukan hanya terdapat dalam rasio, akan tetapi dalam totalitas eksistensi manusia di bumi. Kedua, manusia disebut sebagai gambar Allah di bumi, maka sebenarnya hal itu hendak menegaskan

36 Hoekema, 32. 
bahwa manusia adalah wakil Allah di bumi. Ketiga, kejatuhan dalam dosa memiliki dampak yang sangat serius terhadap gambar Allah, karena mengalami kerusakan yang luar biasa. Keempat, meskipun sudah berdosa, manusia tetap menyandang gambar Allah. Kelima, gambar Allah yang sejati adalah Yesus Kristus dan keenam, melalui Kristus, gambar Allah yang telah rusak dalam diri setiap manusia dipulihkan kembali. Herman Bavinck juga menegaskan bahwa,

"Tugas teologi Kristen untuk menunjukkan gambar Allah di dalam keseluruhan keberadaan manusia. Pertama-tama, Allah dapat dibuktikan dalam jiwa manusia. Kedua, yang termasuk gambar Allah adalah kemampuan-kemampuan manusia. Ketiga, gambar Allah memanifestasikan dirinya di dalam tiga kebajikan: pengetahuan, kebenaradilan, dan kekudusan, yang dengannya manusia telah tercipta sejak awalnya. Keempat, tubuh manusia juga merupakan bagian integral dari gambar Allah. Terakhir, yang menjadi bagian dari gambar ini adalah tinggalnya manusia di firdaus (Kej. 2:8-15)". ${ }^{3}$

Pemikiran Bavinck menunjukkan kesetujuan bahwa gambar Allah mencakup seluruh keberadaan manusia, baik itu tubuh, jiwa, kemampuan, kekuatan, dan karunia-karunia yang dimiliki manusia. Hal yang serupa juga dikemukakan oleh Gerald Bray yang menuliskan:

"Menyamakan gambar Allah dengan pikiran juga memberi kesan bahwa orang-orang yang sangat pandai lebih dekat dengan Allah daripada kita semua... Kita lebih dekat dengan sasaran jika kita menghubungkan gambar dan rupa Allah dengan konsep kepribadian (personhood)., 38

Dengan demikian apa yang telah dikemukakan oleh Banvinck dan Bray di atas mewakili pandangan gereja masa kini tentang gambar Allah. Sekaligus ini merupakan penegasan dalam penelitian, bahwa pandangan Thomas Aquinas yang mengatakan bahwa gambar Allah hanya sebatas pada rasio dan tidak mengalami kerusakan total ketika berdosa adalah sangat keliru dan tidak Alkitabiah. Aquinas

37 Herman Bavinck, Dogmatika Reformed Jilid 2: Allah dan Prolegomena (Surabaya: Momentum, 2012), 697-705.

38 Gerald Bray, Allah Adalah Kasih: Theologi Biblikal dan Sistematis (Surabaya: Momentum, 2020). 
yang menerapkan pemimiran filosofis dalam menjelaskan tentang gambar Allah justru bertentangan dengan apa yang dinyatakan Alkitab tentang gambar Allah.

\section{Analisis Dan Eavaluasi Terhadap Pengajaran Thomas Aquinas Tentang Gambar Allah}

Analisis dan evaluasi ini didasarkan pada konsep gambar Allah menurut ajaran Alkitab yang dibandingkan dengan konsep Thomas Aquinas. Analisis dan evaluasi ini menunjukkan kelemahan dan kesalahan pandangan Aquinas yang berdasar pada filsafat Aristoteles, merendahkan efek dari kejatuhan manusia ke dalam dosa dan menganggap status tubuh lebih rendah dari rasio.

\section{Aquinas Mendasarinya Pada Filsafat Aristoteles Dan Bukan Alkitab}

Plato dan Aristoteles memiliki pandangan bahwa rasio manusia bersifar ilahi, atau rasio manusia merupakan percikan ilahi yang ada dalam diri manusia. Sehingga ketika Aquinas mengemukakan bahwa gambar Allah berada dalam rasio manusia, maka sangat jelas ini didasarkan pada pemahaman Aristoteles atau Plato. Pandangan tersebut berbeda dalam ajaran Alkitab yang dengan tegas dan jelas mengajarkan bahwa gambar Allah mencakup totalitas eksistensi manusia di bumi. Aquinas yang mendasarkan pandangannya pada filsafat Aristoteles adalah sebuah kewajaran, karena dalam biografi Aquinas yang telah dituliskan menunjukkan bahwa Aquinas berasal dari kelompok skolastik, yang mengikuti logika deduktif dari Aristoteles dalam mendekati dan menyelidiki Alkitab.

\section{Aquinas Merendahkan Efek Dari Kejatuhan}

Aquinas juga sangat merendahkan efek yang dimunculkan oleh kerjatuhan dalam dosa. Aquinas mengajarkan gambar Allah sebelum dan sesudah jatuh sama sekali tidak ada masalah atau baik-baik saja. Efek yang diakibatkan oleh kejatuhan adalah manusia hanya kehilangan kuasa supranatural (Lat. donum 
superadditum), di mana donum superadditum ini juga hanyalah tambahan yang diberikan oleh Tuhan agar manusia dapat mengontrol bagian yang terendah dalam dirinya, yakni: emosi. Jadi, donum superadditum bukanlah hal yang esensi bagi manusia. Seperti yang sudah dijelaskan dalam pembahasan sebelumnya, Alkitab dengan jelas dan tegas mengajarkan bahwa karena kejatuhan maka gambar Allah dalam diri manusia mengalami kerusakan yang parah. Tentu, pandangan Alkitab ini bertolak belakang dengan pandangan Aquinas. Dengan kata lain, Aquinas sangat meremehkan kejatuhan dalam dosa.

\section{Aquinas Menganggap Status Tubuh Lebih Rendah Dari Rasio}

Aquinas membedakan antara rasio dengan kekuatan-kekuatan yang lebih rendah dalam diri manusia. Hal ini berdampak kepada pandangan yang menganggap tubuh lebih rendah dari pada rasio, karena tubuh menjadi tempat bagi kekuatan-kekuatan yang lebih rendah. Konsep Aquinas ini bukanlah bersumber dari Alkitab, karena justru Alkitab dengan tegas mengemukakan bahwa gambar Allah juga tercermin dari tubuh. Alkitab sama sekali tidak pernah mengajarkan bahwa ada kekuatan yang lebih rendah dalam diri manusia, sebaliknya manusia diciptakan oleh Tuhan dalam keadaan yang mulia dalam totalitas eksistensinya.

\section{KESIMPULAN}

Pada kesimpulan ini penulis memberikan kesimpulan hasil dari analisis dan evaluasi dengan pendekatan kajian pustaka terhadap pandangan Thomas Aquinas tentang gambar Allah. Penulis berdasarkan pembahasan di atas menguuraikan kesimpulan sebagai berikut, bahwa pandangan Aquinas tentang Gambar Allah sangat tidak Alkitabiah. Oleh karena lebih cenderung kepada 
filsafat Plato dan Aristoteles. Ini merupakan ciri khas dari teologi kelompok skolastik. Selanjutnya, gambar Allah yang disandang oleh manusia tidak hanya terdapat pada rasio saja, melainkan pada totalitas eksistensi manusia di bumi sebagai wakil Allah. Gambar Allah pada manusia mengalami kerusakan yang parah pasca kejatuhan manusia dalam dosa. Rasio tidak lebih baik dari pada tubuh. Dengan kata lain, seluruh bagian dari manusia, baik roh, rasio, moral, tubuh, ketika diciptakan dalam keadaan yang mulia atau sungguh amat baik. Hal ini menolak pandangan Aquinas yang menyatakan bahwa ada kekuatan-kekuatan yang lebih rendah. Terakhir, melalui penelitian ini hendak ditegaskan bahwa gambar Allah yang sejati ada dalam Kristus. Hal ini memberi dampak bahwa hanya melalui Yesus Kristus gambar Allah yang telah rusak parah dapat diperbaiki.

\section{DAFTAR PUSTAKA}

Bauer's, Walter. A Greek-English Lexicon of The New Testament And Other Early Christian Literature (BDAG) Third Edition. Disunting oleh Frederick William Danker. Chicago: The University of Chicago Press, 2000.

Berkhof, Louis. Teologi Sistematika 2: Doktrin Manusia. Surabaya: Momentum, 1995.

Bray, Gerald. Allah Adalah Kasih: Theologi Biblikal dan Sistematis. Surabaya: Momentum, 2020.

Brown, Christopher M. https://www.iep.utm.edu/aquinas/, t.t.

Brown, Collin. Filsafat dan Iman Kristen Jilid 1. Surabaya: Momentum, 2011.

Enns, Paul. The Moody Handbook of Theology 2. Malang: SAAT, 2010.

F. Brown, S. Driver, C. Briggs. The Brown-Driver Briggs Hebrew and English Lexicon. Hendrickson Publishers, 1907. 
Gunawan, Imam. "Metode penelitian kualitatif." Universitas Negeri Malang, 2013. http://fip.um.ac.id/wp-content/uploads/2015/12/3_MetpenKualitatif.pdf.

Hamilton, Victor P. The New International Commentary on The Old Testament: The Book of Genesis Chapter 1-17. Michigan, USA: Grand Rapids, 1990.

Herman Bavinck. Dogmatika Reformed Jilid 2: Allah dan Prolegomena. Surabaya: Momentum, 2012.

Hoekema, Anthony A. Manusia: Ciptaan Menurut Gambar Allah. Surabaya: Momentum, 2003.

“https://id.wikipedia.org/wiki/Thomas_Aquinas," t.t.

“http://www.iep.utm.edu/aquinas/5/6/2013,” t.t.

Patton, Michael Quinn, Budi Puspo Priyadi, dan Kamdani. Metode evaluasi kualitatif. Pustaka Pelajar, 2006.

Pratt, Richard L. Designed For Dignity. Surabaya: Momentum, 2002.

Ramadhon. "Kebahagiaan Dalam Pandangan Thomas Aquinas Dan Hamka." http://journal.uinjkt.ac.id/index.php/una/article/download/15159/pdf, t.t.

Sproul, R.C. Kebenaran-kebenaran Dasar Iman Kristen. Malang: SAAT, 2008.

Timothy Friberg. Analytical Greek Lexicon. Trafford Publishing, 2005. 